\title{
06.01.00 АГРОНОММЯ
}

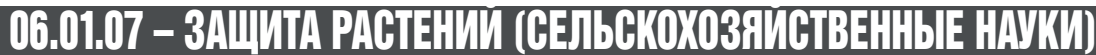

УДК 631.52: $633.11(574.2)$

DOI 10.18286/1816-4501-2021-3-126-130

\section{ГЕНЕТИЧЕСКИЕ РЕСУРСЫ ЯРОВОЙ ПШЕНИЦЫ, УСТОЙЧИВЫЕ К БУРОЙ РЖАВЧИНЕ}

\author{
Бабкенова Сандукаш Амантаевна, кандидат сельскохозяйственных наук \\ Каиржанов Елжас Конспекович, докторант кафедры «Защита и карантин растений» \\ Бабкенов Адылхан Темирханович, кандидат сельскохозяйственных наук \\ ТОО «Научно-производственный центр зернового хозяйства им. А.И.Бараева», 021601, Акмо- \\ линская область, п. Научный, ул. Бараева 15, Республика Казахстан, e-mail: yelzhas_90@mail.ru
}

Ключевые слова: яровая пшеница, генетические ресурсы, бурая ржавчина, сорт, селекция, урожайность, вегетационный период.

Бурая (листовая) ржавчина является наиболее распространенным заболеванием пшеницы и встречается на всех континентах и странах, где возделывается эта культура. В Северном Казахстане посевы яровой пшеницы составляют около 9 млн.га. По данным М.К. Койшыбаева, в северном регионе бурая ржавчина и септориоз проявляются часто совместно, при их распространении в период трубкования-колошения пшеницы и сильном развитии потери урожая достигают 30-40\%, в начале налива-молочной спелости зерна- 7-10 \%. Среди мер защиты растений от разнообразных заболеваний, вызываемых паразитическими грибами, бактериями, вирусами, а также от повреждения различными насекомыми - наиболее действенным средством борьбы является Введение в культуру иммунных сортов. Цель наших исследований - изучить генетические ресурсы яровой пшеницы и выявить новые источники и доноры устойчивости к бурой ржавчине в Северном Казахстане. Подобраны 150 сортов яровой мягкой пшеницы различного эколого-географического происхождения. Коллекционный питомник яровой мягкой пшеницы посеян в 2-х кратной повторности с площадью делянок $2 \mathrm{M}^{2}$. Питомник бурой ржавчины закладывался согласно методике Государственного сортоиспытания сельскохозяйственных культур.

В результате проведенной работы выявлен 31 новый источник устойчивости к бурой ржавчине: к-29288 (Грузия), Stendal (Италия), Сріблянка, ПХРСВ 02 (Украина), Frontana (Бразилия), Marquis (Канада) и др. Характеризовались устойчивостью к бурой ржавчине и комплексом хозяйственно-ценных признаков 7 сортов: Лютесценс 415/00; Лютесценс 120-03; Лютесценс 16-04; Наaтат 4; Сигма; Сибирская 17; Челяба ранняя. Выделенные образцы представляют большой интерес для практической селекции и будут использованы для создания новых сортов яровой пшеницы, обладающих высокой урожайностью и устойчивостью к листовой ржавчине.

\section{Введение}

Бурая (листовая) ржавчина является наиболее распространенным заболеванием пшеницы и встречается на всех континентах и странах, где возделывается эта культура. Возбудитель болезни - гриб Puccinia recondita Desm. (син. Puccinia tritici Eriks.). В Российской Федерации бурая ржавчина в отдельные годы может охватывать большие территории, при сильном развитии болезни потери могут достигать 20-30\%
[1]. В Западной Сибири при эпифитотийном развитии данного заболевания потери зерна достигают 30 \% и урожайность пшеницы снижается до 1,5-2 т/га [2].

В Северном Казахстане посевы яровой пшеницы составляют около 9 млн.га. По данным М.К. Койшыбаева, в этом регионе бурая ржавчина и септориоз проявляются часто совместно, при их распространении в период трубкования-колошения пшеницы и сильном развитии 
потери урожая достигают 30-40\%, в начале налива-молочной спелости зерна - 7-10\% [3]. Следовательно, при средней урожайности яровой пшеницы 1,2 т/га, потери зерна могут достигать 0,12-0,36 т/га. или 1-3 млн.тонн зерна в годы сильного развития бурой ржавчины и септориоза на посевах пшеницы.

И.Г. Одинцова с соавторами полагают, что европейская часть бывшего Советского Союза, Северный Казахстан и Западная Сибирь составляют по бурой ржавчине пшеницы один эпидемиологический район, и популяции возбудителя в этих регионах имеют среднее и сильное сходство [4].

Эти данные подтверждаются исследованиями, проведенными Е.И. Гультяевой, в которых определено высокое генетическое сходство омской популяции с североказахстанской и челябинской и умеренное между челябинской и североказахстанской популяциями [5].

Некоторые исследователи сообщают о возможности распространения инфекции бурой ржавчины из Северного Кавказа в соседние регионы, в частности Северный Казахстан и Западную Сибирь воздушными потоками [6].

Среди мер защиты растений от разнообразных заболеваний, вызываемых паразитическими грибами, бактериями, вирусами, а также от повреждения различными насекомыми - наиболее действенным средством борьбы является Введение в культуру иммунных сортов. Для создания сортов яровой пшеницы, обладающих резистентностью к бурой ржавчине, необходимо проводить изучение коллекционного материала для выявления новых доноров устойчивости к данному заболеванию.

Цель наших исследований - изучить генетические ресурсы яровой пшеницы и выявить новые источники и доноры устойчивости к листовой ржавчине в Северном Казахстане.

\section{Материалы и методы исследований}

Коллекционный питомник закладывался на стационаре отдела селекции яровой пшеницы ТОО «НПЦ ЗХ им. А.И. Бараева» по чистому плоскорезному пару. Подобраны 150 сортов яровой мягкой пшеницы различного экологогеографического происхождения. Коллекционный питомник яровой мягкой пшеницы посеян в 2-х кратной повторности с площадью делянок $2 \mathrm{M}^{2}$ в соответствии с методическими указаниями ВИР по изучению коллекции пшеницы [7]. Посев проведен 25 мая сеялкой ССФК-7, уборка делянок осуществлялась селекционным комбайном Wintersteiger.
В период вегетации растений проводились фенологические наблюдения для определения продолжительности межфазных периодов и вегетационного периода [8].

Устойчивость сортов к поражению болезнями определяют на основе двух ведущих показателей: 1) по внешнему проявлению реакции растения - хозяина на вторжение патогена; 2) по интенсивности проявления заболевания. Устойчивость образцов пшеницы к бурой ржавчине определяли в условиях искусственного заражения. Питомник бурой ржавчины закладывался согласно методике Государственного сортоиспытания сельскохозяйственных культур [9]. Посев семян проводили в оптимальные для зоны сроки (20-25 мая), сеялкой СКС-6-10. Для контроля через 10-20 образцов изучаемого материала высевали восприимчивый стандарт Акмола 2.

Инфекционные питомники бурой стеблевой ржавчины и септориоза закладывали на расстоянии 7-10 км от селекционных питомников и производственных посевов пшеницы и изолированных от них лесополосами. Для инокуляции использовали синтетические популяции Puccinia recondita, полученные из ННИ продуктов биобезопасности, п. Отар. В день заражения споры прогревали в течение 30 минут при температуре $45^{\circ} \mathrm{C}$, затем выдерживали во влажной камере в течение 6 часов и определяли жизнеспособность спор. Норма расхода спор $10 \mathrm{Mг} \mathrm{всхожих} \mathrm{спор} \mathrm{на} 1 \mathrm{M}^{2}$. Заражение проводили в вечернее время в фазу выхода растений в трубку - начало колошения. Перед заражением опытные делянки обильно поливали водой, растения опыляли смесью спор с мукой в соотношении 1:100. После заражения делянки накрывали полиэтиленовой пленкой, которая снималась через 12-18 часов [10]. Реакцию испытуемых образцов на ржавчину оценивали по следующей шкале: 0-иммунный, R - устойчивый, MR - умеренноустойчивый, MS - умеренновоспримчивый, S - воспримчивый по общепринятой методике [11]. Интенсивность поражения растений определяли по шкале E.B. Mains., H.S Jakson [12].

Учёты поражаемости образцов ржавчинными заболеваниями проводили не менее 2 раз. Первый - через 8-10 дней после заражения при проявлении на восприимчивых образцах первых пустул, второй раз - через 10 дней. Технология посева и заражения растений стеблевой ржавчиной в инфекционном питомнике аналогична с методикой оценки к бурой ржав- 
Таблица 1

Иммунологическая оценка сортообразцов яровой мягкой пшеницы на устойчивость к бурой ржавчине

\begin{tabular}{|c|c|c|c|}
\hline \multirow[b]{2}{*}{ Сортообразец } & \multirow{2}{*}{$\begin{array}{c}\text { Происхож- } \\
\text { дение }\end{array}$} & \multicolumn{2}{|c|}{ Поражение } \\
\hline & & $\begin{array}{l}\text { Тип ре- } \\
\text { акции }\end{array}$ & $\begin{array}{c}\text { Интенсив- } \\
\text { ность, \% }\end{array}$ \\
\hline Акмола 2, стандарт & Казахстан & $\mathrm{S}$ & 80 \\
\hline Лютесценс 415/00 & Россия & $\mathrm{R}$ & 5 \\
\hline Лютесценс 120-03 & Россия & 0 & 0 \\
\hline Александрина & Россия & $\mathrm{R}$ & 5 \\
\hline Лютесценс 16-04 & Россия & MR & 5 \\
\hline Лютесценс п 23-18 & Россия & MR & 10 \\
\hline Лютесценс 205/03-1 & Россия & MR & 10 \\
\hline Сибирская 17 & Россия & $\mathrm{R}$ & 5 \\
\hline Лютесценс 1147 & Россия & 0 & 0 \\
\hline Лютесценс 126-05 & Россия & 0 & 0 \\
\hline Лютесценс 128-05 & Россия & $\mathrm{R}$ & 5 \\
\hline Сигма & Россия & $\mathrm{MR}$ & 10 \\
\hline Челяба ранняя & Россия & 0 & 0 \\
\hline Уральская кукушка & Россия & MR & 10 \\
\hline Haamam 4 & Сирия & $\mathrm{R}$ & 5 \\
\hline Ghurab 2 & Сирия & 0 & 0 \\
\hline Croc1/ae.squarrosa22 & Мексика & $\mathrm{MR}$ & 30 \\
\hline Самгау & Казахстан & $\mathrm{MR}$ & 5 \\
\hline K-29288 & Грузия & $\mathrm{R}$ & 10 \\
\hline Stendal & Италия & $\mathrm{R}$ & 10 \\
\hline Сріблянка & Украина & 0 & 0 \\
\hline Пхрсв 02 & Украина & 0 & 0 \\
\hline Елегія миронівська & Украина & $\mathrm{MR}$ & 10 \\
\hline Любава & Беларусь & $\mathrm{MR}$ & 10 \\
\hline Немчиновская 1 & Россия & $\mathrm{R}$ & 70 \\
\hline Юбилейная 80 & Россия & 0 & 0 \\
\hline Frontana & Бразилия & 0 & 0 \\
\hline Marquis & Канада & 0 & 0 \\
\hline BW 252 & Канада & 0 & 0 \\
\hline AC Pomain & Канада & 0 & 0 \\
\hline ND 000597 BUTE 86 & США & $\mathrm{R}$ & 10 \\
\hline PI590576 KULM & США & $\mathrm{R}$ & 5 \\
\hline
\end{tabular}

чине.

\section{Результаты исследований}

Начальным этапом создания исходного материала для селекции сельскохозяйственных растений на невосприимчивость к болезням является формирование банка источников устойчивости. Для этого в 2018-2020 гг. в условиях искусственного инфекционного фона была проведена иммунологическая оценка сортообразцов яровой пшеницы к возбудителю Puccinia recondita, представленных различными экологогеографическими группами: России, Украины, Грузии, Италии, Бразилии, Канады и Казахстана.

В результате скрининга по устойчивости к бурой ржавчине выделены 22 резистентных образца яровой мягкой пшеницы: к-29288 (Грузия), Stendal (Италия), Сріблянка, ПХРСВ 02 (Украина), Frontana (Бразилия), Marquis (Канада) (таблица 1). В группу умеренно-устойчивых, отнесены 9 образцов яровой мягкой пшеницы: Лютесценс 16-04, Лютесценс П 23-18, Лютесценс 205/03-1; Сигма (Россия), Елегія миронівська (Украина), Любава (Беларусь), Croc1/Ae.Squarrosa22 (Мексика), Уральская кукушка (Россия) и Самгау (Казахстан).

В наших исследованиях стандартный сорт Акмола 2 сформировал урожайность 276 г/м², превысили стандарт по данному показателю 4 сорта: Лютесценс 415/00; Лютесценс 120-03; Лютесценс 16-04; Лютесценс 128-05 (табл. 2). Вегетационный период стандартного сорта составил 98 дней, созревали раньше стандарта 13 образцов: К-29288; Stendal; Пхрсв 02 и др. К самым скороспелым, которые созревали раньше Акмолы 2 на 10 дней и более, можно отнести следующие 4 сорта: Сигма; Уральская кукушка; Haamam 4 и Самгау. Стандартный сорт Акмола 2 сформировал продуктивную кустистость 1,8 шт. Высокой продуктивной кустистостью характеризовались 6 образцов: Лютесценс 415/00; Лютесценс 120-03; Александрина; Лютесценс 16-04; Лютесценс 126-05; Marquis. Число зерен в колосе у сорта Акмола 2 составило 33 шт., по данному показателю превысили стандарт 4 сорта: Лютесценс п 23-18; Сибирская 17; Сигма; Челяба ранняя. По массе зерна с колоса превысили стандарт Акмола 2 два сорта: Лютесценс 120-03 и Сибирская 17. Одним из основных элементов продуктивности является масса 1000 зерен. 4 образца сформировали массу 1000 зерен более 40 г: Лютесценс 415/00; Лютесценс 120-03; Челяба ранняя; Haamam 4.

\section{обсуждение}

При создании нового сорта селекционер должен учитывать множество факторов, обеспечивающих адаптивность сорта к конкретным почвенно-климатическим условиям, позволяющим получать стабильно высокий урожай зерна. Поэтому среди образцов, выделенных по устойчивости к бурой ржавчине, была проведена оценка по комплексу хозяйственно-ценных признаков, таких как урожайность, скороспелость и основные элементы продуктивности.

По комплексу хозяйственно-ценных признаков выделены следующие образцы: Лютесценс 415/00; Лютесценс 120-03; Лютесценс 16-04; Haamam 4; Сигма; Сибирская 17; Челяба ранняя. Образец Лютесценс 415/00 сформиро- 
Таблица 2

Урожайность, вегетационный период и основные элементы структуры продуктивности сортов яровой пшеницы, 2018-2020 гг.

\begin{tabular}{|c|c|c|c|c|c|c|c|c|}
\hline Сортообразец & $\begin{array}{c}\text { Происхож- } \\
\text { дение }\end{array}$ & $\begin{array}{c}\text { Урожай- } \\
\text { ность, г/ } \\
\text { M }^{2}\end{array}$ & $\begin{array}{c}\text { Вегетацион- } \\
\text { ный период, } \\
\text { сутки }\end{array}$ & $\begin{array}{c}\text { Высота } \\
\text { растения, } \\
\text { см }\end{array}$ & $\begin{array}{c}\text { Продуктивная } \\
\text { кустистость, } \\
\text { шт. }\end{array}$ & $\begin{array}{c}\text { Число } \\
\text { зерен в } \\
\text { колосе, } \\
\text { шт. }\end{array}$ & $\begin{array}{c}\text { Масса } \\
\text { зерна с } \\
\text { колоса, г. }\end{array}$ & $\begin{array}{c}\text { Мacca } \\
1000 \text { зе- } \\
\text { рен, г. }\end{array}$ \\
\hline Акмола 2 & Казахстан & 276 & 98 & 77 & 1,8 & 33 & 1,28 & 38,3 \\
\hline Лютесценс 415/00 & Россия & 282 & 98 & 69 & 2,0 & 25 & 1,01 & 41,1 \\
\hline Лютесценс 120-03 & Россия & 401 & 99 & 82 & 2,5 & 33 & 1,35 & 41,6 \\
\hline Александрина & Россия & 250 & 90 & 71 & 2,2 & 24 & 0,87 & 36,8 \\
\hline Лютесценс 16-04 & Россия & 337 & 97 & 78 & 2,3 & 32 & 1,22 & 38,0 \\
\hline Лютесценс п 23-18 & Россия & 236 & 95 & 70 & 1,4 & 34 & 1,23 & 35,6 \\
\hline Сибирская 17 & Россия & 270 & 98 & 83 & 1,5 & 38 & 1,48 & 38,5 \\
\hline Лютесценс 1147 & Россия & 251 & 96 & 70 & 1,7 & 27 & 0,98 & 36,0 \\
\hline Лютесценс 126-05 & Россия & 219 & 95 & 70 & 1,9 & 33 & 1,14 & 34,3 \\
\hline Лютесценс 128-05 & Россия & 278 & 100 & 67 & 1,5 & 30 & 1,10 & 36,6 \\
\hline Сигма & Россия & 146 & 85 & 63 & 1,0 & 36 & 1,06 & 29,6 \\
\hline Челяба ранняя & Россия & 251 & 97 & 82 & 1,6 & 39 & 1,66 & 42,6 \\
\hline Уральская кукушка & Россия & 182 & 87 & 64 & 1,8 & 29 & 0,86 & 30,4 \\
\hline Haamam 4 & Сирия & 119 & 86 & 47 & 1,1 & 29 & 1,18 & 40,9 \\
\hline Самгау & Казахстан & 169 & 83 & 64 & 1,4 & 25 & 0,98 & 39,2 \\
\hline K-29288 & Грузия & 174 & 91 & 60 & 1,4 & 22 & 0,76 & 32,6 \\
\hline Stendal & Италия & 144 & 93 & 45 & 1,2 & 27 & 1,02 & 37,1 \\
\hline Пхрсв 02 & Украина & 129 & 92 & 52 & 1,4 & 20 & 0,69 & 33,5 \\
\hline Frontana & Бразилия & 146 & 108 & 78 & 1,4 & 32 & 1,16 & 36,6 \\
\hline Marquis & Канада & 143 & 107 & 73 & 2,1 & 31 & 0,87 & 28,0 \\
\hline
\end{tabular}

вал урожайность 282 г/м², что на 6 г выше чем у стандартного сорта. Данный образец превышает стандарт по продуктивной кустистости на 0,2 шт., массе 1000 зерен на 2,8 г и характеризуется высокой устойчивостью к бурой ржавчине (5R). Линия Лютесценс 120-03 созревала на уровне сорта Акмола 2, но превышала его по урожайности на 125 г. Превышение по урожайности обеспечивалось за счет таких элементов продуктивности, как продуктивная кустистость - 2,5 шт., масса зерна с колоса - 1,35 г и масса 1000 зерен - 41,6 г. Реакция на поражение бурой ржавчиной у данного образца составила 0 баллов. Большой интерес для селекции представляют скороспелые образцы. Так, сорт Сигма созревал на 13 дней раньше стандартного сорта, но при этом уступал ему по урожайности. К другим преимуществам данного сорта относится его короткостебельность - 63 см. По устойчивости к бурой ржавчине относится к умеренным сортам - 10MR. Сорт Haamam 4 так же как и сорт Сигма характеризуется скороспелостью - 86 дней, короткостебельностью - 47 см и высокой устойчивостью к бурой ржавчине - $5 R$.

\section{Заключение}

В результате проведенных исследований выявлен 31 новый источник устойчивости к бурой ржавчине: к-29288 (Грузия), Stendal (Италия), Сріблянка, ПХРСВ 02 (Украина), Frontana (Бразилия), Marquis (Канада) и др. Характеризовались устойчивостью к бурой ржавчине и комплексом хозяйственно-ценных признаков 7 сортов: Лютесценс 415/00; Лютесценс 120-03; Лютесценс 16-04; Haamam 4; Сигма; Сибирская 17; Челяба ранняя. Выделенные образцы представляют большой интерес для практической селекции и будут использованы для создания новых сортов яровой пшеницы, обладающих высокой урожайностью, скороспелостью и устойчивостью к листовой ржавчине.

\section{Библиографический список}

1 Санин, С. С. Фитосанитарная обстановка на посевах пшеницы в Российской Федерации (19912008) Аналитический обзор / С. С. Санин // Защита и карантин растений. - 2010. - № 2. - С. 70-87.

2 Создание генетического разнообразия пшеницы по устойчивости к болезням в условиях Западной Сибири / В. П. Шаманин, И. В. Потоцкая, А. С. Чурсин, О. Г. Кузьмин, С. С. Шепелев, В. Е. Пожерукова, А. И. Моргунов // Идеи Н.И. Вавилова в современном мире : тезисы докладов IV Вави- 
ловской Международной конференции. - СанктПетербург, 2017. - С. 332-333.

3 Койшыбаев, М. Болезни пшеницы. (Продовольственная и сельскохозяйственная организация ООН (ФАО)) / М. Койшыбаев. - Анкара, 2018. $-365 c$.

4 Связь между популяциями возбудителя бурой ржавчины пшеницы на территории СССР и ее значение для селекции / И. Г. Одинцова, Л. Ф. Шеломова, А. А. Аманов, Х. О. Пеуша // Защита растений. - 1989. - № 3. - С. 13-18.

5 Структура популяций листовых патогенов яровой пшеницы в западноазиатских регионах России и Северном Казахстане в 2017 году / Е. И. Гультяева, Н. М. Коваленко, В. П. Шаманин, В. А. Тюнин, Е. Р. Шрейдер, Е. Л. Шайдаюк, А. И. Моргунов // Вавиловский журнал генетики и селекции. - 2018. - № 22(3). - С. 363-369.

6 Михайлова, Л. А. Особенности взаимоотношений патогенов и растение-хозяина в патосистемах Pyrenophora tritici - repentis - Triticum Cochlibolus sativus - Triticum / Л. А. Михайлова, Н. М. Коваленко, С. Г. Гоголева // Фитосанитарное оздоровление экосистем : материалы Междуна- родной научной конференции. - Санкт-Петербург, 2005. - С. 515-518.

7 Пополнение, сохранение в живом виде и изучение мировой коллекции пшеницы, эгилопса и тритикале : методические указания / А. Ф. Мережко, Р. А. Удачин, Е. В. Зуев [и др.]. - СанктПетербург : ВИР, 1999. - 81 с.

8 Методика оценки селекционных форм и сортов мягкой пшеницы при испытании на отличимость, однородность и устойчивость к факторам среды : методические рекомендации / В. А. Зыкин, Л. П. Росеева, И. А. Белан, Р. К. Кадиков. -Уфа, 2004. - 39 c.

9 Методика проведения сортоиспытания сельскохозяйственных растений. - Астана, 2011. -126 с.

10 Методические указания по оценке сортов зерновых культур на устойчивость к ржавчине в полевых условиях. - Москва : Колос, 1975. - 8 с.

11 Wheat Rusts / Mclntosh [et al.] // An Atlas of Resistance Genes. CSIRO. - Australia, 1995. - 200 p.

12 Mains, E. B. Physilogic Specialisation in the Leaf Rust of Wheat Puccinia triticiana Erikss / E. B. Mains, H. S. Jackson // Phytopatology. - 1926. - № 16. - P. 89-120.

\title{
GENETIC RESOURCES OF SPRING WHEAT RESISTANT TO BROWN RUST
}

\author{
Babkenova S.A., Kairzhanov E.K., Babkenov A.T. \\ TOO "Scientific and Production Center of Grain Farming named after A.I. Baraev", 021601, Akmola \\ region, Nauchnyi v., Baraeva st., 15, Republic of Kazakhstan, e-mail: yelzhas_90@mail.ru
}

\begin{abstract}
Key words: spring wheat, genetic resources, brown rust, variety, selection, productivity, growing season.
Brown (leaf) rust is the most common wheat disease and is found on all continents and countries where this crop is cultivated. Spring wheat occupies about 9 million hectares in Northern Kazakhstan. According to M.K. Koishybaev, brown rust and Septoria spot often appear together in the northern region, when they spread during the shooting-earing period and in case of wide progression, yield losses reach 30-40\%, at the beginning of the filling- grain milk ripeness period 7-10\%. Among plant protection measures from various diseases caused by parasitic fungi, bacteria, viruses, as well as from damage by various insects, the most effective is introduction of immune varieties into the culture. The aim of our research is to study the genetic resources of spring crops and to identify new sources and donors of leaf rust resistance in northern Kazakhstan. In total, 150 varieties of spring bread wheat of various ecological and geographical origin were selected. The collection seed plot of spring soft wheat was sown in 2 replications, with a plot area of $2 \mathrm{~m} 2$. The brown rust plot was lain according to the methodology of the State Variety Testing of Agricultural Crops. As a result of the work carried out, thirty-one new sources of resistance to leaf rust were identified: $k$-29288 (Georgia), Stendal (Italy), Sriblyanka, PKHRSV 02 (Ukraine), Frontana (Brazil), Marquis (Canada), etc. Seven varieties were characterized by resistance to leaf rust and a complex of economically valuable traits: Lutescens 415/00; Lutescens 120-03; Lutescens 16-04; Haamam 4; Sigma; Sibirskaya 17; Chelyaba early. The selected samples are of great interest for practical breeding and will be used to create new varieties of spring wheat with high productivity and resistance to leaf rust.
\end{abstract}

Bibliography:

1. Sanin S.S. Phytosanitary Situation on wheat crops in the Russian Federation (1991-2008) Analytical Review/S.S. SANIN// Plant protection and quarantine. -2010. - № 2. - P. 70-87.

2. Creation of genetic diversity of wheat by disease resistance in Western Siberia / V.P. Shamanin, I.V. Pototskaya, A.S. Chursin, O. G. Kuzmin, S.S. Shepelev, V.E. Pozherukova, A.I. Morgunov //"Ideas of N.I. Vavilov in the modern world ": Abstracts of the IV Vavilov international conference. - St. Petersburg, 2017. - P. 332-333.

3. Koishybaev, M. Wheat diseases. (Food and Agriculture Organization of the United Nations (FAO)) / M. KOISHYBAEV. - Ankara, 2018.- 365 p.

4. Connection between populations of wheat leaf rust agent in the USSR and its importance for breeding / I.G. Odintsova, L.F. Shelomova A.A. Amanov, Kh.O. Peusha // Plant Protection. - 1989. - № 3. - P. 13-18.

5. Population structure of leaf pathogens of spring wheat in the West Asian regions of Russia and Northern Kazakhstan in 2017 / E.I. Gultyaeva, N.M. Kovalenko, V.P. Shamanin, V.A. Tyunin, E.R. Schrader, E.L. Shaydayuk, A.I. Morgunov // Vavilov Journal of Genetics and Breeding. - 2018. - No 22 (3). - P. 363-369.

6. Mikhailova, L.A. Peculiarities of the relationship between pathogens and the host plant in the pathosystems Pyrenophora tritici - repentis - Triticum Cochlibolus sativus - Triticum / L.A. Mikhailova, N.M. Kovalenko, S.G. Gogoleva // materials of the international scientific conference "Phytosanitary Rehabilitation of Ecosystems". - SPb, 2005. - P. 515-518.

7. Merezhko, A.F., Udachin R.A., Zuev E.V. Replenishment, preservation in a life form and study of the world collection of wheat, aegilops and triticale: guidelines /A.F. Merezhko, R.A. Udachin, E.V. Zuev. - SPb.: VIR, 1999.- 81 p.

8. Methodology for assessing breeding forms and varieties of common wheat when testing for distinctness, uniformity and resistance to environmental factors. - Ufa, 2004.- $39 p$.

9. Methodology for conducting variety testing of agricultural plants. - Astana, 2011.- $126 \mathrm{p}$.

10. Guidelines for assessment of grain varieties for resistance to rust in field conditions. - M.: Kolos, 1975.- $8 p$.

11. Mclntosh et al. Wheat Rusts / An Atlas of Resistance Genes. CSIRO. - Australia, 1995.- 200 p. $89-120$

12. Mains, E.B. Physiologic Specialization in the Leaf Rust of Wheat Puccinia triticiana Erikss / E.B. Mains, H.S. Jackson // Phytopathology. - 1926. - No 16. - P. 